\title{
北海道における薬用作物栽培の特徵
}

\section{Characteristics of Medicinal Crop Production in Hokkaido, Japan}

\author{
石田 奈菜
}

Nana ISHIDA ${ }^{1}$

\begin{abstract}
要旨
漢方薬の国内需要が高まるなか, 原料の生薬は約 8 割を中国産に頼っている。しかし, 中国産生薬の価格は毎年上昇しているため, 国内自給率を上げることが求められている。特に北海道は大規模栽培が可能なこと, 寒冷地向きの作物を栽培できることから注目 されている。薬用作物は連作障害が多いこと, 栽培方法が確立されていないこと, 登録農薬が少ないこと, 生薬への加工が必要な こと，市場がなく製薬会社との契約栽培になることなど，他の作物と異なる点が多い。本研究では，北海道に打ける薬用作物栽培 の実態を, 帯広市のセンキュウ栽培, 千歳市のトリカブト栽培, 石狩市のソヨウ栽培, 夕張市の夕張ツムラの工場, 名寄市のカ, コソウ栽培の事例から報告する。その際, 栽培規模や輪作の状態, 薬用作物栽培の課題や利点などに注目した。各生産地で共通して, 自然条件などに適した薬用作物の選定や生産者の生産力，販路の確保，輪作体系に組み込めるかなどが重要であることがわかった。
\end{abstract}

キーワード：薬用作物，生薬，北海道，製薬会社

\section{I . はじめに}

\section{1. 研究背景と目的}

漢方薬とは，植物などの天然物を加工した生薬を組 み合わせて調剤されたものである。近年，健康志向 の高まりから漢方薬の需要が高まっている。原料で ある生薬は，8割ほどを中国からの輸入に頼っている が, 価格は毎年上昇している（日本漢方生薬製剤協会, 2015，2016）。そのため, 薬用作物や生薬の自給率を 高める動きが盛んになっている。薬用作物は, 生薬へ の加工が必要であること，連作障害が多いこと，含有 成分の基準を満たさなければならないこと，単年で収 穫できないものがあること，栽培技術が確立していな いことなど，他の作物と異なる点が多い。そこで，産 地化の支援として，農林水産省を中心に，「薬用作物 の生産及び需給情報等に関するブロック会議」（農林 水産省, 2015）や「薬用作物等地域特産作物産地確立 支援事業」（農林水産省，2017）などが行われている。 特に北海道は，寒冷地向きの植物の栽培に適している こと，大規模栽培が可能なことなどから注目されてい る。実際に 2016 年産では, 薬用作物の生産量 3 位, 栽培面積 1 位で国内の一大産地になっている（日本特 産農産物協会, 2017)。本研究では北海道内の各生産 地における薬用作物の生産と加工の事例を報告する。

\section{2．北海道における薬用作物栽培の実態}

図 1 は北海道における薬用作物の栽培面積と全国に 占める割合を示したものである。1999 年に落ち达む が，概ね拡大している。全国に占める割合も，変動は あるものの徐々に高くなっている。面積が縮小した 2015 年も約 15\%を維持している。困 2 は北海道の各 市町村における薬用作物の栽培面積をまとめたもので ある。薬用作物の栽培は, $1 \sim 2$ 種類の作物に特化し ているところが多い。産地との相性に加え，高収益な 輪作作物として導入するため 1 ～種類で十分だと考 えられる。一方で、大樹町や夕張市など，品目の多い

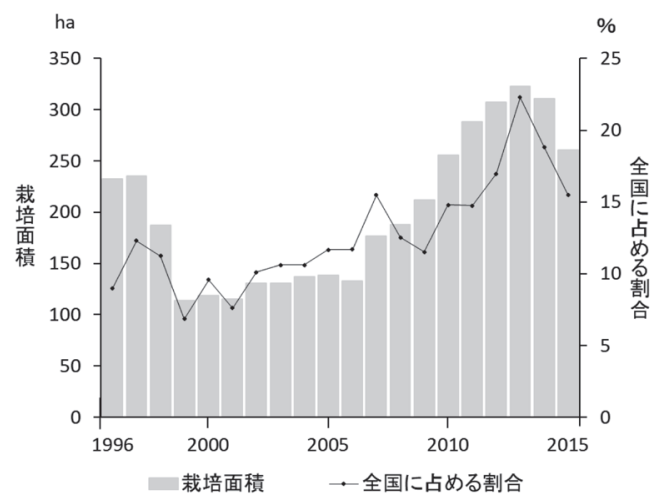

図 1 北海道に打ける薬用作物の栽培面積と全国に占める割合 日本特産農産物協会「薬用作物（生薬）に関する資料」をもと に作成

${ }^{1}$ 元北海道大学文学部学生 / Former student, Hokkaido University, Japan 


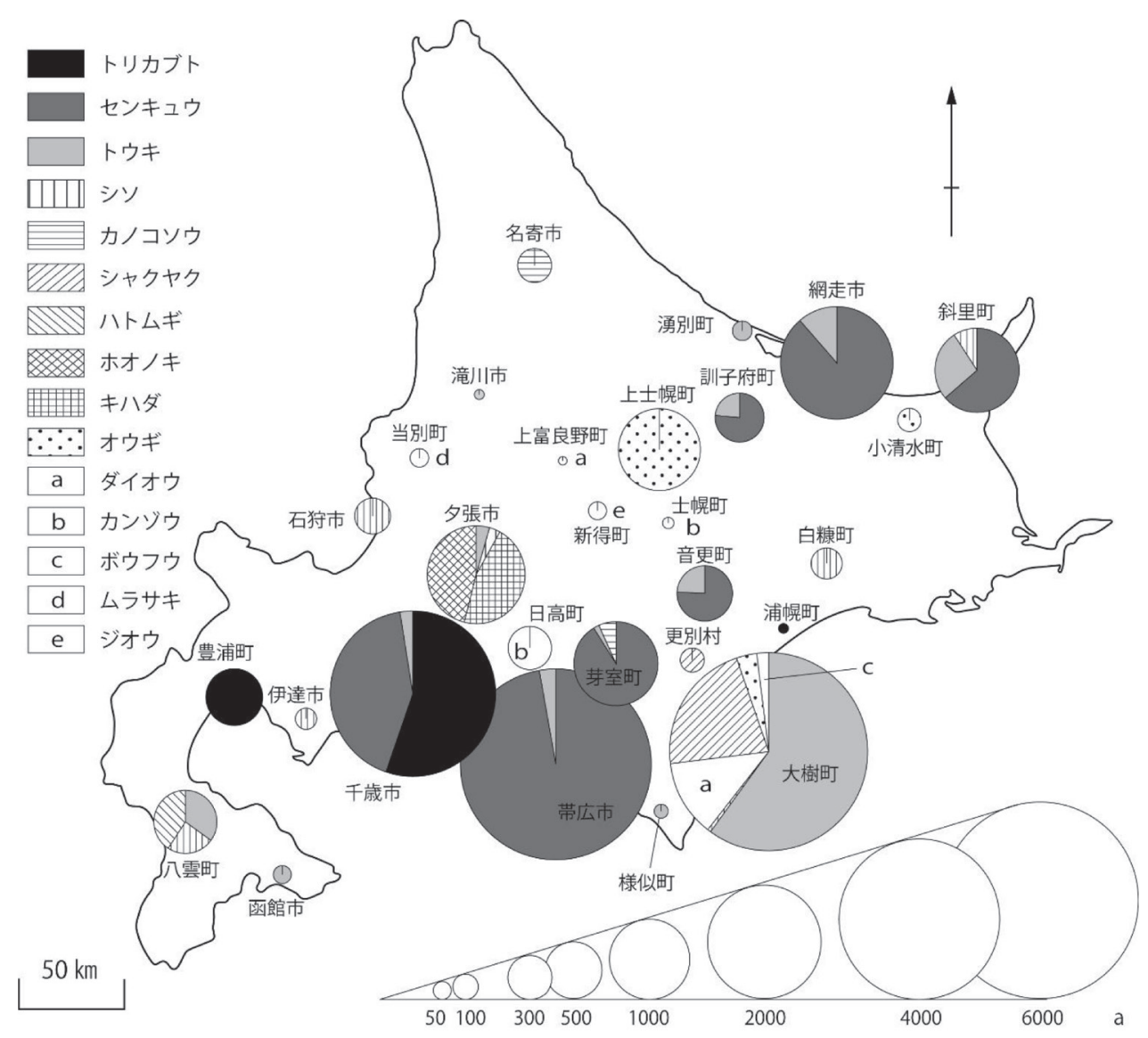

図2 北海道における薬用作物の市町村別栽培面積

日本特産農産物協会「薬用作物（生薬）に関する資料」をもとに作成

ところもある。大樹町は 2012 年には統計がなかった が, 2014 年は 2 品目 $2,900 \mathrm{a}, 2015$ 年は 6 品目 6,095 a と大幅に拡大している。夕張市は自社農場を持つ「夕 張ツムラ」が立地する。試験的な栽培を大規模に行っ ているのではないだろうか。

以下，主要な薬用作物栽培の事例として，带広市の センキュウ栽培, 千歳市のトリカブト栽培, 石狩市の ソヨウ栽培を紹介する。上記の 3 産地と契約する夕張 ッムラの取り組みも併せて紹介する。また, これらと は別ルートで生産を行う名寄市のカノコソウ栽培も紹 介する。

\section{II. 北海道における栽培の事例 \\ 1. 帯広市におけるセンキュウ栽培 \\ ( 1 ） センキュウとは}

センキュウは, 生薬「川芦」として利用され, 用途 は補血, 強壮, 鎮静, 鎮痛などである。当帰药薬散な どに配合される。利用部位は塊状の根茎であり, 湯通 しと乾燥したものを使う。寒冷地が適地で, 北海道で 多く栽培される。また，排水の良い場所で肥沃地を好 む。繁殖は栄養繁殖で, 種イモを用いる（厚生省薬 務局，1993）。日本特産農産物協会（2015）によると, 2013 年の生産量は多い順から带広市 $279.7 \mathrm{t}$, 千歳市 $116.0 \mathrm{t}$, 幕別町 $100.0 \mathrm{t}$, 網走市 $67.7 \mathrm{t}$, 芽室町 $61.0 \mathrm{t}$ などと, 特に十勝地方やオホーツク地方で盛んである。

\section{（2）生産の実態}

JA 帯広かわにしの A 氏及びセンキュウ栽培農家の $\mathrm{B}$ 氏への聞き取り調査の結果は以下の通りである。川 西地区全体で薬用作物を栽培している農家は 16 戸で, うちセンキュウは 14 戸5 ha（2017）である。収量 の上下は他の作物より大きいと感じている。取材を行 った戸蔦地区で薬用作物栽培が始まったのは, 1987 年のことである。津村順天堂（現（株）ツムラ）が带 広かわにしに薬用作物の栽培の話を持ちかけ, 当時の 担当者が川西地区内の戸蔦地区に打診して始まった。 気候との相性や機械化の成功, 収益性, 輪作体系に組 み达めること，ある程度大きい面積で栽培できること など，条件に適したセンキュウが選ばれた。戸蔦地区 は, 山が近く比較的冷涼で, 地温も低い地域である。 夕張ツムラの担当者は, 带広は夏に暑くなるが, 戸蔦 地区は比較的涼しいため, 元々山の中で生育するセン キュウの栽培に適していると考えている。1戸あたり の耕地面積は, 約 40 ha と大きい農家が多い。コムギ, マメ類, バレイショ, ビートの畑作 4 品目の輪作が基 本で，その中にセンキュウを組み込んでいる。図 3 は センキュウ農家の輪作体系である。センキュウの収穫 にはバレイショの機械を活用するなど，機械化が進ん でいる。薬用作物だからといって, 戋場は隔離されて はいない。

B 氏は，現在 $47 \sim 48$ ha の畑で生産を行っている。 


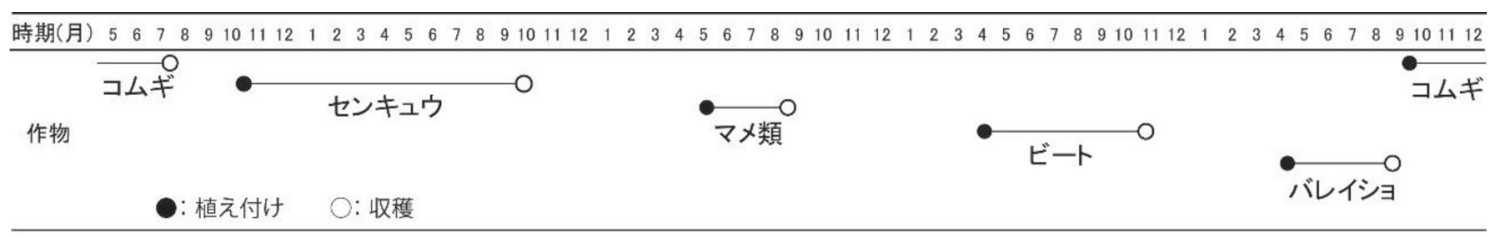

図 3 センキュウ農家の輪作体系 聞き取り調査をもとに作成

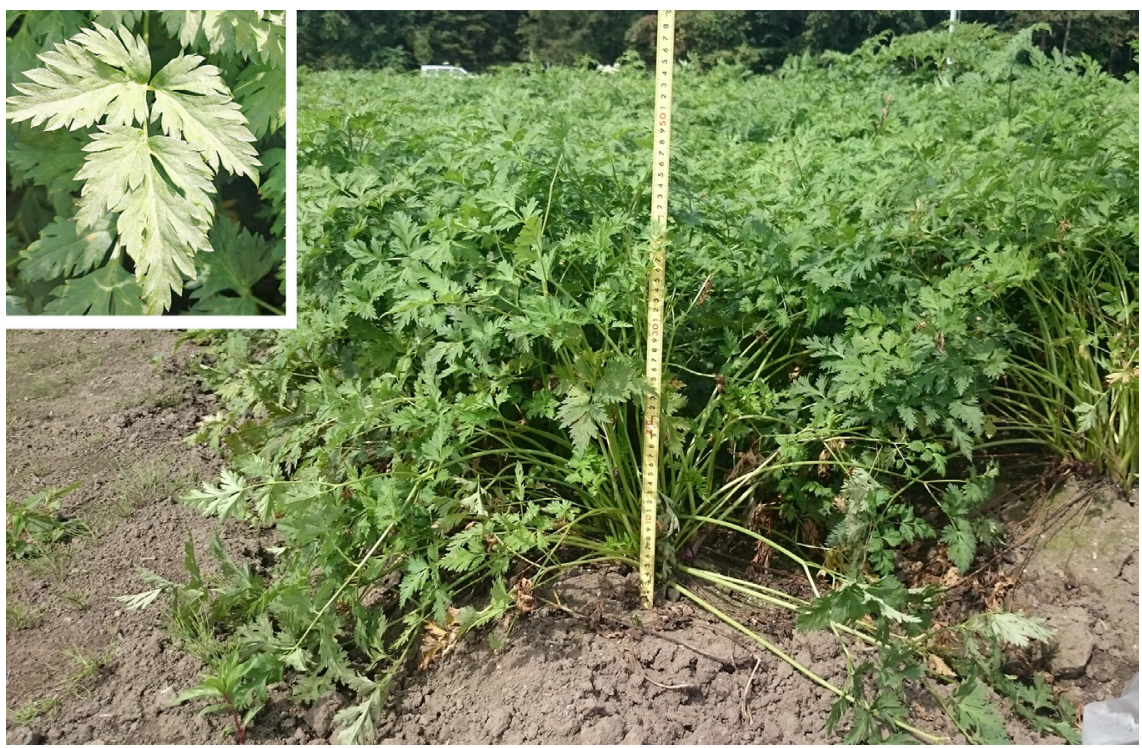

図 4 B 氏のセンキュウの固場（2017 年 9 月 11 日，筆者撮影）

内訳は、コムギ 20 ha, バレイショ 10 ha, ビート 7 ha, センキュウ 5.5 ha, 金時豆などのマメ類 3 ha と なっている。図 4 はB Eのセンキュウの圑場であり， 畑に隙間がないほど繁茂していた。センキュウは, 土 壤改良の関係で，コムギの収穫後に肥料を足して植え 付ける（図 3 )。翌年の秋に収穫し, その後はマメ類, ビート, バレイショ,コムギとなる。収穫後は泥落と し, 乾燥, 選別といった加工を自分たちで行う。基本 的に家族経営で，10月の子株分けと 11 月の選別の時 に 7 ～ 8 人のパートを雇う。毎年依頼している人の高 齢化や，ビートや川西地区で生産が盛んな長芋などの 作業と重なるため，労働力の確保が課題である。戸蔦 地区は特に耕作面積が大きく, 手作業は嫌われるため, 農薬を使えるようにすることも大きな課題である。ま た，他の作物と違い，共済に加入できないため，災害 時のリスクが大きい。

\section{2. 千歳市におけるトリカブト栽培}

\section{（1）トリカブトとは}

トリカブトは，生薬「附子」として利用され，用途 は, 鎮痛, 利尿, 強心などである。利用部位は塊根で, 水洗い後乾燥させたものを使う。附子湯などに配合さ れる。冷涼な気候に適し, 国内では北海道が産地であ る。排水及び保水の良い場所で, 肥沃地に適し, 栄養 繁殖を行う（厚生省健康政策局創薬・新医療技術研究 会, 1999)。図 5 は北海道におけるトリカブトの市町 村別生産量を示したものである。2007 年から徐々に

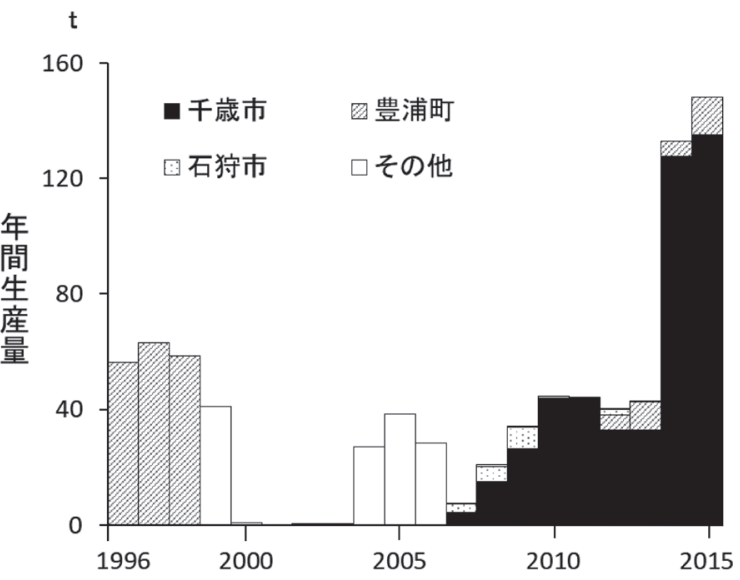

図 5 北海道におけるトリカブトの市町村別生産量 日本特産農産物協会「薬用作物（生薬）に関する資料」を もとに作成

千歳市の生産量が増え, 2015 年には 135 tで道内の生 産量の大部分を占めるようになった。

\section{（２）生産の実態}

2003 年に夕張ツムラから市を通して J A に打診が あり，2004 年に試験栽培が開始された。2010 年には J A に薬草生産部会が設立され，生産が拡大した。東 千歳の保水力がある土壇や冷涼な気候が適していたと いう（北海道新聞, 2015 年 5 月 26 日朝刊）。

JA どうおうのC 氏及びトリカブト栽培農家の D 氏 への聞き取り調査の結果は以下の通りである。千歳市 では，2015 年は 23 戸 44 ha でトリカブトやセンキュ 


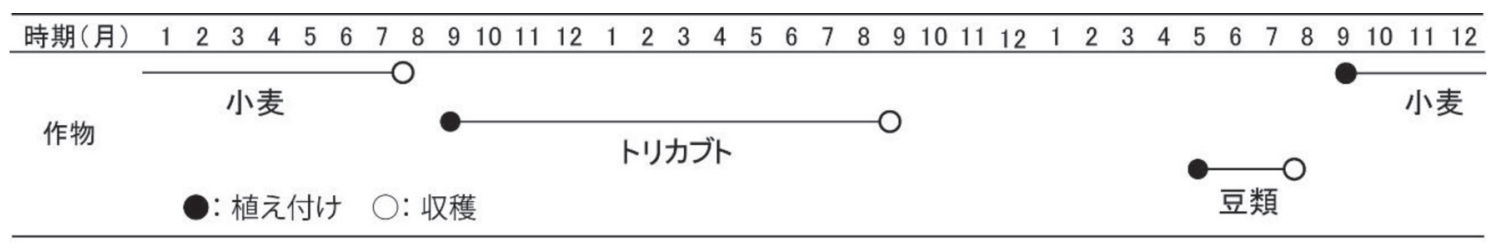

図 6 D 氏の輪作体系

聞き取り調査をもとに作成

ウを栽培している。 $\mathrm{D}$ 氏が栽培を始めたのは，蔬菜生 産部会の役員だったときに，話を持ちかけられたこと がきっかけである。10 aで栽培を始め, 夕張ツムラ の提示した目標を上回ったため生産を拡大した。現在, D 氏が所有する畑は 23 haで，コムギ（春秋合わせて） 7.5 ha, バレイショ 2.5 ha, トリカブト 2.5 ha, ダイ ズ 2.3 ha，センキュウ 2 ha, 貸地 7 ha である。図 6 はD 氏の輪作の様子を示したものである。元々，コ ムギ, ダイズ, アズキ, バレイショに野菜やビートを 加えて経営していたが, 収益を上げるため薬用作物を 導入した。野菜やビートは 5 ha ほどつくっていたが, 2016 年でやめた。東千歳地区のトリカブト栽培はツ ムラの中で, 日本最大の面積である。トリカブトは毒 性があるが，アピールにならないよう，あえて囲いな どはしていない。現在は，成分が製薬に適しているが 収量がやや少ない品種を栽培しており，増収が目標だ という。窒素肥料がポイントだとわかってきたため, マニュアルを作成している。機械も導入しており，先 行事例の岩手では手作業だった植え付けにはポテトプ ランター, 収穫はビートハーベスターとポテトディガ ーを使用している。

現在の問題は, 殺菌歳と殺虫剤の効果が弱く, 立ち 枯れが発生していることである。繁忙期のパートの確 保が難しいことも課題である。また，バレイショや豆 と収穫時期が被ることがある。秋は霜が降りるため作 業時間が $11 〜 16$ 時くらいと短く, 両立ができずトリ カブトの栽培をやめた農家もあった。

薬用作物の利点は収益性であるという。10 a 当た りの粗収入で, 普通の作物は 10 万円, 野菜は 20 万円, ビートは $12 \sim 13$ 万円が目標だが，薬用作物は 15 万 円前後と高い。さらに，人件費は少しかかるが，農薬 をあまり使用できないこともあり，経費があまりかか らないという。

\section{（3）JA 道央 附子集出荷施設について}

トリカブトは収穫後に放置するとカビが生えるた め, 生産拡大に伴い, ツムラが加工施設を建設した。 さらにその隣に, 国の「2014 年度強い農業づくり事業」 による補助金と農協の出資で，トリカブト $175 \mathrm{t}$ を収 容できる集出荷貯蔵施設を建設した。2017 年, この JA では，9月 20 日ごろに収穫の指示をした。各農家 が集出荷貯蔵施設に収穫したトリカブトを運び込み, 30 ～ 40 人で生薬となる塊根から細い子根を外す。こ の年は天候の影響で, やや遅れて 10 月からの作業に なった。子根外しが終わると, $10{ }^{\circ} \mathrm{C}$ 以下の予冷庫で 保管される。次に隣の加工施設でカットと乾燥が行わ
れ，製品倉庫に移される。そして集出荷貯蔵施設に戻 され，2015年に導入した選別機で選別して出荷され る。この施設によって収穫後の作業はスムーズになっ た。

\section{3．石狩市におけるソヨウ栽培}

\section{（1）ソヨウとは}

ソヨウとは, 赤シソである。葉や枝先に乾燥を施 し, 生薬「蘇葉」として利用される。睡眠延長, 鎮静 作用などがあるとされ，香蘇散などに配合される（木 村ほか, 2007)。図 7 は北海道におけるソヨウの市町 村別生産量である。2010 年からは北海道でも生産さ れており, 入れ替わりながらも生産する市町村が増え, 2015 年には 6 市町となっている。生産地も道央, 道南, オホーツク地域と広い。

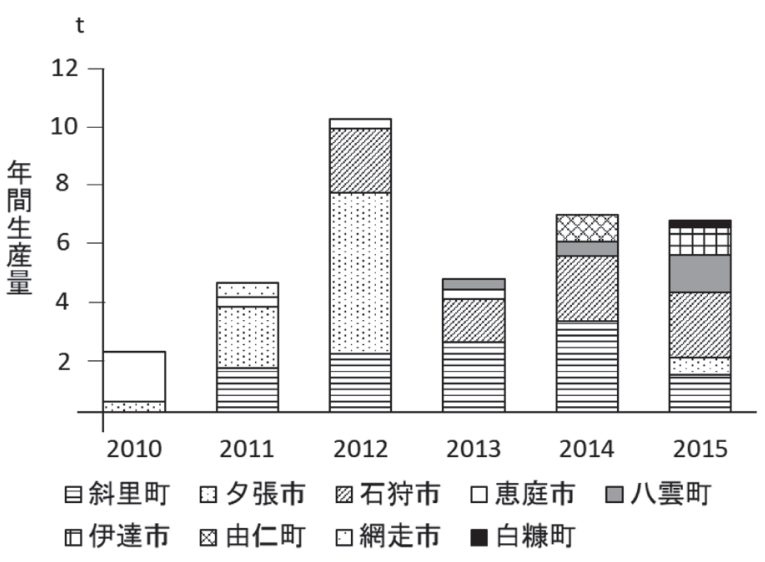

図 7 北海道におけるソヨウの市町村別生産量 日本特産農産物協会「薬用作物（生薬）に関する資料」を もとに作成

\section{（2）生産の実態}

「てみるファーム」代表の E 氏への聞き取り調査の 結果は以下の通りである。てみるファームは，障害の ある人の就労支援を行う社会福祉法人の「はるにれの 里」が 2010 年に設立した農業生産法人である。ソヨ ウなどを夕張ツムラに販売する一方で，はるにれの里 が運営する「ふれあいきのこ村」で菌床シイタケ栽培 を行っている。利用者は 14 人で, 発達障害など様々 な人がいるため, 施設職員がそれぞれの性格や得意不 得意，その日の天候などで仕事を振り分けている。て みるファームでは烟を 10 ha 保有しており, 2 ha はソ ヨウ, 1 ha は他の作物, 残りは貸地や遊休地になっ ている。ソヨウは露地栽培で, 一部でマルチがけを行 っていた。圑場は海が近く，砂質の土壤だった。3〜 
4 月にハウスで育苗，5～6月に植え付け， 7 月末〜 10 月は収穫を行う。収穫は, 茶刚り機で上 $5 \mathrm{~cm}$ ほど を刈り取る。成長が早いため，20～30 回ほど㺫り取 りができる。刚り取りが遅いと花芽が出てしまい，早 いと枝が混入するため, 収穫のタイミングも重要であ る。花芽が出るまで繰り返し, 最後にすべての葉を手 で摘み取る。収穫後は, 変色する前に近くの施設で乾 燥させる。3 日ほど撹拌しながら送風機で温風を当て て乾燥させ, 袋に詰めて出荷する。夕張ツムラとは, $\mathrm{kg}$ 単位での出来高制の契約となっているが, 露地栽培 で天候に左右されることからノルマはない。

薬用作物栽培を始めたきっかけは，キノコの作業が 切れる夏に畑作を始めようと, 夕張ツムラが設立され た際に，E氏が問い合わせたことである。2010年に 夕張ツムラから担当者が来て, 栽培が始まった。苦労 した点は, 薬の原料であるから農薬を控えるよう夕張 ツムラから指導されているため, 除草が手作業になる ことである。また，選別の基準や乾燥具合に適度に対 応することにも苦労した。

夕張ツムラという販路先が確保されていることは大 きな利点である。夕張ツムラは利用者に生薬の利用方 法を紹介する勉強会を行っている。これによって，利 用者は「育てたソヨウが, 薬になって人の役に立って いる」という自信をもって働いているという。また, ソヨウの葉は赤く, 雑草は緑色のため, 「赤はとらな いで, 緑だけ取って」というように作業の指示が伝わ りやすいことも利点である。

\section{4. 夕張ツムラの取り組み}

夕張ツムラはツムラの子会社として 2009 年 7 月に 創業した。道内で生産された薬用作物を集め, 漢方薬 の原料である生薬に加工し, ツムラへ販売する。ツム ラは売上高の $95.5 \%$ が医療用漢方製剤である（株式会 社ツムラ, 2016)。2016 年度の医療用漢方製剤の市場 では, シェア $84 \%$ を占める（漢方のツムラ）。ツムラ の国内自給率は $15 \%$ で, うち約半分は夕張ツムラが 占める。夕張ツムラの工場に集められた薬用作物や生 薬は, $5{ }^{\circ} \mathrm{C}$ 以下のチルド保管庫で保管される。スライ ス, 乾燥を経て, 中間原料として温度 $15{ }^{\circ} \mathrm{C}$ 以下, 湿 度 60 \% 以下の低温・低湿で保管される。後に選別と 品質検査を行い, 茨城県の石岡センターへ輸送される。 ここで選別や加工が行われた後, 茨城工場または静岡 工場へ送られ, 切裁や調合, 抽出, 造粒などを経て医 薬品代理店に納品される。現在, 夕張ツムラは, 会社 の周辺の遊休農地や耕作放棄地を借り上げて自社農場 とし, 薬用作物の栽培も行っている。夕張は山間地の ため, 1〜2 ha ほどの畑を 10 数か所, 合計 20 ha 程 度で, 農家に避けられる多年生の作物などを植えてい る。畑同士が離れていて交雑の心配がないため, 種苗 づくりなどにも利用している。農薬や栽培技術の試験 や会社を訪れた人への実演の役割もある。人手不足や 放棄地で除草が大変だということもあり, 現在は生産 可能な範囲に縮小している。かわりに滝川市の畜産試
験場跡地を借り，自社農場として生産を拡大させてい る。規模は 147 ha で, 土壤改良が済み栽培を行って いるのは 62 ha である。ソヨウや多年生のシャクヤク などを栽培し, 障がい者施設への農作業委託も行って いる。

ツムラは道内各地で生産を行う計画があったため, 新千歳空港や茨城との航路がある苫小牧港, 各産地と の中間地点にあり，アクセスが比較的良い夕張市を選 んだ。雇用創出など，財政破綻した夕張市への地域貢 献の意味もあったという。夕張ツムラは「ともに生 き, ともに歩む」を揭げており，六次産業化と社会福 祉法人との連携に取り組んでいる。六次産業化は, 薬 用作物の生産, 生薬や漢方薬への加工, 販売といった, ツムラの事業そのものである。これをより充実させる ため, 夕張ツムラは, 2014 年に農業生産法人となり, 2015 年には総合化事業計画に認定され，制度や資金 のバックアップを受けられるようにした。また，社会 福祉法人との連携には, 上記の「てみるファーム」の 事例があてはまる。

北海道で生産を行ってもらうためには, 生産体系を 崩さずに薬用作物を導入できるかが重要である。帯広 市のセンキュウはコムギの収穫後に植え付けができた こと, 道内で栽培を開始したオウギはゴボウと共通点 が多いことから導入できた。導入後は, 小規模な栽培 から規模を拡大することが難しいという。農家との契 約は，農協などの生産団体との契約をしている。一気 に契約を失うリスクもあるが, 契約戸数の確保や管理 がしやすい。また, 標準書を産地に配布し, 均一な生 産を目指している。世界基準の管理, GMP 認定 ${ }^{1)}$ の 取得が目標である。

\section{5. 名寄市におけるカノコソウ栽培 （1）カノコソウとは}

カノコソウは, 生薬「吉草根」として利用され, 用 途は鎮静薬である。利用部位は根及び根茎であり, 土 砂の洗浄と乾燥を施す。排水が良い肥沃地に適し, 連 作障害が激しいため, 4〜 5 年の輪作が必要とされる。 繁殖は株分けによって行う（厚生省薬務局, 1995)。

\section{（2）生産の実態}

名寄市農業振興センターのF 氏に 2016 年および 2017 年に聞き取り調査を行い, 名寄市薬用作物研究 会によるカノコソウ栽培に関する情報をまとめたもの が表 1 である。年々, 生産戸数と栽培面積が伸びてい る。栽培面積の $1 / 5 \sim 1 / 4$ は翌年の株を残すため, 出 荷面積とは一致しない。カノコソウは, 1 株から 3 4 株に殖やせる。また，連作圃場で生育不良などが見 られるため, 名寄市農業振興センターは, イネ科の後 に栽培し, 土壤中の病原菌やセンチュウの密度を下げ るよう指導している。研究会所属農家の耕地面積のう ちカノコソウの割合は, 一戸のみ $3 \%$ で, 他は $1 \%$ 以 下である。契約メーカーの希望を順調に満たしつつあ る。5 月に定植し, 10 月上旬に収穫, 中旬から洗浄, 11 月に乾燥, 12 月に出荷となる。 
表 1 名寄市薬用作物研究会によるカノコソウの栽培状況

\begin{tabular}{|c|c|c|c|}
\hline 年 & $\begin{array}{l}\text { 生産 } \\
\text { 戸数 }\end{array}$ & $\begin{array}{c}\text { 栽培 } \\
\text { 面積 (a) }\end{array}$ & 状況 \\
\hline 2012 & 1 & 2.5 & 試験栽培開始 \\
\hline 2013 & 1 & 24 & 研究会設立, トレファノサイド乳刜承認 \\
\hline 2014 & 12 & 142 & セレクト乳剤承認 \\
\hline 2015 & 13 & 183 & \\
\hline 2016 & 14 & 203 & 春の干ばつ, 台風で栽培に苦戦 \\
\hline 2017 & 14 & 206 & \\
\hline
\end{tabular}

名寄市では，当時の市長が国立衛生研究所北海道薬 用植物栽培試験場（現薬用植物資源研究センター）を 誘致したことから，1960 年代中頃には様々な薬用作 物が栽培されていた。カノコソウも生産されており, 日本特産農産物協会（2008）によると, 国産生薬（株） を通して問屋・メーカーに出荷していた。2013 年には, これとは別に, 18 戸による「名寄市薬用作物研究会」 が設立され，カノコソウの栽培が始まった。この研究 会によって，機械の共同利用や製薬会社との複数年契 約の締結, 効率的な栽培試験ができた。特に, この研 究会は洗浄·乾燥機の改良と農薬の登録に力を入れた。 国の補助事業を使い, カノコソウ専用の洗浄機と乾燥 機を製作し，作業時間の短縮に成功した。また, マイ ナー作物登録制度 ${ }^{2)}$ を利用し, トレファノサイド乳 剂 (播種前の土壤処理剂), とセレクト乳剂（イネ科 の除草剂）の使用が承認された。

カノコソウの利点は, 収益性が高いこと, 今後の 需要増が期待され価格が安定していること, 単年で収 穫できることである。加えて，冷涼な気候を好み，名 寄市でも生産実績があり情報を得やすい点が挙げられ る。

\section{II. おわりに}

北海道における薬用作物栽培の特徵をまとめると, (1)導入する作物の選定が重要であること，(2) 1 つの産 地で $1 \sim 2$ 種類の作物が導入されることが多いこと, (3)大規模栽培に対応するため機械化や農薬の登録が欠 かせないこと，(4)製薬会社との契約や販路の確保が必 要なこと, (5)生産者や生産団体に十分な資本力や労働 力，栽培技術や経験が求められることである。特に(1) では, 気候や土壤との相性や, 現在の輪作体系を崩さ ずに導入できること，収益性が高いことなどを複合的 に考えなくてはならない。収益性の高さや他地域での 成功のみから作物を決めつけて栽培をするのではな く，丁寧に産地に適する作物の選定が重要である。

\section{謝辞}

取材に応じてくださったJA带広かわにし様, かわにし薬用 作物生産組合長様, JA 道央千歳営農センター様, 千歳市薬草 生産組合長様, てみるファーム様, 夕張ッムラ様, 名寄市農業 センター様, 薬用植物資源研究センター様, 北海道大学大学院 先端生命科学研究院次世代ポストゲノム研究棟科学生物学研究 室様, 北海道立衛生研究所様, 卒業論文の作成にあたってご指
導いただいた仁平尊明先生へ,この場を借りてお礼申し上げま す。なお, 本研究は北海道大学文学部に提出した平成 29 年度 卒業論文の一部である。

\section{注}

1) GMP (Good Manufacturing Practice) は，医薬品製造業 者に対し原材料の入庫から，製品の製造・加工，出荷に至 るまでのすべての過程で, 製品が適切かつ安全に作られ, 一定の品質が保証されるように，遵守することが求められ ている基準。(http://www.mhlw.go.jp/shingi/2009/03/dl/ s0330-12c_0113.pdf 2018 年 2 月 19 日閲覧)

2 ) 農薬試験をメーカーに代わり都道府県が行える制度であ る。マイナー作物に使える農薬を登録しやすくなる。産 地の要望を受けた各都道府県が試験を行い, デー夕を農 薬メーカーに提出し， 登録してもらう（http://www.maff. go.jp/j/syouan/syokubo/boujyo/pdf/taisei.pdf 2018 年 2 月 19 日閲覽)。

名寄市薬用作物研究会のカノコソウでは, 日本植物調整 剂研究協会, 薬用植物資源研究センター, 名寄市農業振興 センターの 3 つの機関での試験結果をもって, 農薬の登録 が行われた。

\section{文献}

株式会社ツムラ（2016）:『ッムラグループ コーポレートレポー ト』2016, 44

木村孟淳·田中俊弘·水上元 (2007) : 『改訂生薬学改訂第 6 版』. 南 江堂, 136 .

漢方のツムラ：「ツムラのビジネス『07. 医療用漢方製剤の市場 動向』」http://www.tsumura.co.jp/zaimu/business/bsn/07. html（最終閲覽日 2017 年 12 月 21 日）

厚生省薬務局 (1993)：「薬用植物 栽培と品質評価」Part 2, 25-34.

厚生省薬務局（1995）：「薬用植物 栽培と品質評価」Part 4, $15-24$.

厚生省健康政策局創薬・新医療技術研究会（1999）：「薬用植物 栽培と品質評価」Part 8, 43-49.

日本漢方生薬製剂協会（2015）：『第 3 回中国産原料生薬の価格 指数調査 http://www.nikkankyo.org/aboutus/investigation/ kakaku-chousa/kakaku-chousa_003.html（最終閲覧日 2017 年 6 月 15 日)

日本漢方生薬製剤協会 (2016)：『原料生薬使用量等調査報 告書 $(4)$ 一平成 25 年度抒よび 26 年度の使用量』http:// www.nikkankyo.org/aboutus/investigation/pdf/shiyouryouchousa04.pdf（最終閲覽日 2017 年 6 月 15 日）

日本特産農産物協会（2008）：「薬用植物（生薬）に関する資料」, 26.

日本特産農産物協会 (2015) : 「薬用植物 (生薬) に関する資料」, 6 . 日本特産農産物協会（2017）：「薬用作物及び和紙原料等に関す る資料」, 3 .

農林水産省（2015）:『平成 27 年度薬用作物の産地化に向け たブロック会議の開催及び参加者の募集について』http:// www.maff.go.jp/j/press/seisan/tokusan/150831_1.html（最終 閲覧日 2017 年 7 月 3 日) 
農林水産省（2017）：『平成 29 年度予算概算要求の概要 30 薬 用作物等地域特産作物産地確立支援事業』http://www.maff. go.jp/j/budget/2017/attach/pdf/index-53.pdf（最終閲覧日 2017 年 7 月 3 日)

(2018 年 4 月 12 日受理) 